\title{
Psychology of Male and Female Communicative Activity
}

\author{
Svetlana A. Vasyura \\ Udmurt State University (Russia)
}

\begin{abstract}
The article features a brief overview of theoretical and empirical studies in communication psychology and sociability of men and women, boys and girls. Russian and foreign studies are summarized to point out that girls and women place greater emphasis on communication and interpersonal relations than do boys and men. Moreover, female communication is more emotional. The article presents the results of the author's own empirical study of male and female communicative activity. Communicative activity is viewed as a complex psychological phenomenon, a degree of the subject's willingness to interact. Communicative activity was studied with the test proposed by the Russian psychologist, Krupnov, and designed to detect the following components of communicative activity: dynamic (natural), emotional, motivational, cognitive, regulatory, productive, and two sorts of communication difficulties (operational and personal). Gender differences in communicative activity are shown on a sample of 480 participants aged 18-40 (240 men and 240 women). The article then describes communicative styles of adolescents (130 boys and 130 girls, aged 19-24). Various communicative styles are featured, including "energetic, businesslike," "conformal, emotional," "diplomatic, externally oriented" for boys and "energetic, sociable," "emotional, difficult," and "complaisant, expressive" for girls. Every person's individuality and gender identity are shown to impact their communicative style.

Keywords: communicative activity, gender, integral individuality, style of communicative activity
\end{abstract}

El artículo presenta una revisión de los estudios teóricos y empíricos de la psicología de la comunicación y la sociabilidad de hombres y mujeres, chicos y chicas. Se resumen estudios rusos y extranjeros y se indica que chicas y mujeres ponen mayor énfasis en la comunicación y en las relaciones interpersonales que los chicos y hombres. Además, la comunicación femenina es más emotiva. El artículo presenta los resultados del estudio de la autora sobre la actividad comunicativa de varones y mujeres. La actividad comunicativa se ve como un fenómeno complejo psicológico, un grado de la voluntad del sujeto a interactuar. Se estudió la actividad comunicativa con el test propuesto por al psicólogo ruso, Krupnov, diseñado para detectar los siguientes componentes de la actividad comunicativa: dinámico (natural), emocional, motivacional, cognitivo, regulativo, productivo, y dos tipos de dificultades de comunicación (operacional y personal). Se observan las diferencias de género en la actividad comunicativa en una muestra de 480 participantes de edades entre 18-40 años (240 varones y 240 mujeres). El artículo describe estilos comunicativos de adolescentes (130 chicos y 130 chicas, edades entre 19-24). Se observan varios estilos comunicativos, incluyendo "energético" "práctico [businesslike]," "conformista, emocional," "diplomático, orientado externamente" para chicos y "energético, sociable," "emocional, difícil," y "complaciente, expresivo" para chicas. Se observa que la individualidad e identidad de género afectan el estilo comunicativo de las personas.

Palabras clave: actividad comunicativa, género, individualidad integral, estilo de actividad comunicativa

Correspondence concerning this article should be addressed to Svetlana A. Vasyura, Universitetskaya str., 1-6-104, Izhevsk, Udmurt Republic, RUSSIA, 426034. Phone: +7 (3412) 916-122. E-mail: vasyura@udm.ru 
Psychology in Russia has long been "sexless," with studies of gender differences scarce. Today, gender issues are highly relevant and actively discussed by the scientific community. The gender approach in humanistic sciences is quickly developing, although there is still some heterochronism in various sciences. Gender issues have also become highly relevant for practical psychologists.

Attention to gender differences and relations between men and women is not surprising. On the one hand, women are becoming increasingly representative in various professional spheres in Russia, while, on the other hand, stereotypes-traditional unfair social prejudices based on sex-still have negative impact on women, leading to inferiority complex and lower self-esteem.

Stereotypes of masculinity-femininity (or gender stereotypes) play an important role in the socialization of children and adolescents and regulate their behavior. However, the concepts of masculinity and femininity have recently started changing and becoming ambiguous. Traditional differences in behavior are fading in the world of coeducation of boys and girls and are changing professional specifics. For example, girls and women practicing a "male" profession display a masculine way of thinking and character. They may face an incongruity, when their success in a traditionally male profession is assigned to a lack of femininity (a role conflict takes place). At the same time, the development of masculine behavior in boys is hindered by the predominance of female teachers in Russian schools fostering feminine qualities. Moreover, in the family, boys tend to communicate mostly with women.

Negative consequences of masculinity-femininity stereotypes are also noteworthy. For example, traditional Russian concepts of male and female attributes can hinder or prevent the development of qualities that do not match the gender-role stereotypes. Boys have been shown to have more difficulties in developing labor skills and such qualities as persistence, diligence, and accuracy. At the same time, girls are more patient and accurate, but they show less initiative (Rudey, 1987).

According to Yufereva (1985), teenagers and adolescents form their concepts of masculinity and femininity in course of communication with the opposite sex. At different ages, such concepts reflect different aspects of communicationfamily life and closer relations between boys and girls, with former concepts gradually replaced by new ones. According to this author, the change of communication spheres plays an important role in the formation of psychological gender.

During puberty, gender-conditioned behavior usually becomes predominant, explained by the increasing genderrole pressure at this age. In a study of 16-17-year-olds, boys were shown to communicate with a more practical orientation, whereas girls turned out to be more expressive (Tyrnova, 1996).

In general, psychological differences between men and women and boys and girls are very convincing. However, there are still unanswered questions, and empirical studies are lacking. One of the aspects requiring special attention is gender differences in communicative activity. Many Russian (Bodalev, 1996; Burakova, 2000; Groshev, 2002; Kornienko, 2001; Kuznetsova, 1987; Pogolsha, 1998; Tyrnova, 1996; Vasyura, 2002; Vizgina \& Panteleev, 2001; Yufereva, 1985; Znakov, 2005) and other psychologists (Bem, Martina, \& Watson, 1976; Buunk, Vanyperen, Taylor, \& Colling, 1991; Eagly, 1995; Helgeson, 1994; Tannen, 1991) are researching these issues.

In course of socialization, communication and relationships become more important for women, as compared to men. Gender differences in the amount of communication and stronger orientation of women towards interpersonal communication have been described (Bodalev, 1996). Girls are reported to be more relaxed in their communication with boys than vice versa. Moreover, they communicate more passively, but tend to be more friendly and selective (Groshev, 2002).

In adolescent groups, boys were shown to communicate more practically with fewer tools and methods used and stricter control over their emotions. Girls are more expressive and tend towards internality (i.e., active social self-regulation; that is, relying on one's own knowledge, power, and opportunities in interpersonal contacts and the belief that one's communicative relations with partners depend on one's own initiative) in the self-regulation of communication (Tyrnova, 1996). During adolescence, communication with peers of the same or different gender has been shown to impact self-perception as a personality of a certain sex. Such perception is formed in communication with peers of the same sex in boys and with the opposite sex in girls.

Men have been shown to interrupt women twice as often, with women following the communicative initiative of men, who try to enhance the importance of their ego in the genderverbal dialog (Groshev, 2002). It is also noteworthy that influential men and women possess some qualities of the opposite sex - men possess feminine qualities such as understanding the interlocutor, whereas women have a masculine drive (Pogolsha, 1998).

Recent studies have shown that men and women are viewed differently as subjects of obstructed and unobstructed communication. A woman striving to reinforce intimacy with her partner, being subordinate and accepting, is considered a subject of unobstructed communication. Men adopting such type of relationships are considered subjects of obstructed communication. Men are considered to be subjects of unobstructed communication when they dominate, show interest, suspicion, and strive to be benevolent (Labunskaya, Medzheritskaya, \& Breys, 2001).

In general, Kon (1988) note that the masculine lifestyle is objective and instrumental, while the feminine one is emotional and expressive. Masculine communication is characterized by greater emotional restraint, whereas women can express their feelings and emotions more fully and freely 
in a conversation. Buunk, Vanyperen, Taylor, and Collins (1991) point out that women express stronger tendency toward affiliation than men do.

Tannen (1991) has shown that men and women follow different rules of communication behavior. She notes that a conversation between men and women is an interaction of opposite cultures. This investigator also points out several reasons for the misunderstanding between different sexes. For example, men like to be informed, have freedom of action, and independence of judgment. At the same time, women strive for intimacy with their partners and reinforce close relationships.

Most studies of gender differences are based on biological (biogenetic) or social concepts. The first approach is based on humoral, morphologic, and neurophysiologic peculiarities, and the second approach, on social factors. The most popular point of view states that social factors play the most important role in communicative gender differences. The communicative style is determined by the need to adhere to the masculinity/femininity standards. Both approaches may be complementary and explain various aspects of gender differences. The system approach, which may be based on the integral individuality theory by Merlin (1981) and the general systems theory (Bertalanfy, 1968) seems to show promise in the gender-based studies of communication. Merlin considers integral individuality as a large self-regulating system, consisting of relatively closed hierarchical levels: biochemical, somatic, neurodynamic, personal, and socio-psychological. Integral individuality presumes special links between all personal attributes. Merlin's theory allows the combination of gender (biology) and gender-role differences (social psychology), whereas the object of system analysis is a person as an integral selfdeveloping system.

In the Perm psychological school, theoretical and experimental studies of communicative activity, based on the integral individuality concept, are led by Vyatkin (2006). The communicative style is seen as a backbone in the mediation and harmonization of heterogeneous links within the integral individuality.

One of the recent trends in the Perm psychological school are gender-based communication and individuality issues. Firstly, such studies have shown that the integral individuality description should always include gender aspects (Moshkina, 2000;). Secondly, gender aspects of various activities have been studied, for example, studying and its role in the integral individuality (Volochkov, 2002). In younger schoolboys, studying has been shown to play a more significant role in the integral individuality as compared to girls. In schoolgirls of the same age, studying compensates for situational (school) anxiety. According to Gorbunov (1992), girls differ from boys in volitional activity and individual attributes, which may be characterized as different individual styles of volitional activity. In adolescents, Ustalov (2006) studied styles of psychological defense, the person's adaptation to the social reality. This author reports that girls and boys prefer different styles of psychological defensemasculine aggression for boys and emotional irrationality and rational control for girls.

Also, research of the Perm psychological school focuses on communication in different ages and life situations (Shmykov, 1996; Vasyura, 2002; Kornienko, 2001, 2003). Communicative activity is considered to be a person's integral characteristic. Shmykov studied convicts' communication in a stressful life situation and showed that their communicative style is a multi-level and multicomponent system, conditioned by various levels of integral individuality. Earlier studies in teen samples showed that, in the course of their development, communicative style determines the structure of the teen's integral individuality. Research of male and female communication is of theoretical and practical value. Studies of the structure of communicative activity and its place in the person's individuality will clarify the psychology of optimal and obstructed communication between men and women, and the reasons for harmonic or inharmonic development of their individuality.

In psychology, the complex phenomenon of communicative activity is viewed from various perspectives. The analysis of such studies shows that the psychological aspects of the term "communicative activity" are not yet completely clear. There are several major approaches to sociability. The motivational approach focuses on internal incentives for communication and is based on psychoanalytical concepts. The second behavioral approach places special emphasis on external behavioral aspects of sociability. The pragmatic approach studies the impact of sociability on the person's performance. The last collective approach defines sociability as a set of related attributes.

Krupnov's (1995) model of communicative activity is a system of motivational, notional, instrumental, and style characteristics, facilitating interpersonal interaction. The first two characteristics of communicative activity include motivational, cognitive, and productive aspects, whereas instruments and style include dynamic, emotional, and regulatory aspects. The motivational component is diagnosed by socio- and egocentric incentives. The cognitive component is characterized, on the one hand, by the degree of consciousness of sociability and awareness of its role, and on the other hand, by the general awareness, that is, the earnestness of judgments, the ability to delimit sociability from other personal attributes. The productive component is evaluated by the result of communication in the objective and subjective spheres.

The dynamic aspect of communication may be characterized by the desire to communicate, the initiative to get to know new people, and the extension of the circle of contacts (ergicity), or its restriction and the person's unwillingness to communicate (anergicity). In the emotional component, sthenic (joy, admiration, optimism, etc.) and 
asthenic emotions (fear, anxiety, stress, uneasiness, etc.) were assessed. The regulatory component of communicative activity is characterized by the active or passive type of selfregulation. In general, the instruments and style of communication have pretty well-defined poles, with ergicity, sthenia, and internality on the one side, and anergicity, asthenia, and externality on the other.

According to Krupnov (1995), motivational and notional characteristics are mostly determined by external environmental factors, whereas instruments and style largely depend on the natural neurophysiologic attributes of the personality.

In general, this study is based on the main principles of Russian psychology - the unity of biological and social aspects and the systems approach to the person's psyche. The main principles of the Merlin's (1981) theory of integral individuality are of special importance to this study. In addition, I base my research on the works of Vyatkin (2006) and Krupnov (1995), and the descriptions of gender aspects of communication by Bodalev (1996), Groshev (2002), and other psychologists.

My goals were the following: (a) to detect differences in communicative activity of men and women, in absolute measures and in structure; (b) to determine the male and female concepts of a difficult communication partner of the same and opposite sex; and (c) to describe and compare communicative styles of girls and boys, determined by different-level features of individuality. My hypotheses were as follows:

1. The communicative activity of men and women differs in structure and the expression of various components.

2. Males' and female' concepts of a difficult communication partner of the same and opposite sex are different.

3. Both the male and female samples display multiple communicative styles (systems influenced by various levels of the integral individuality). In these samples, communicative styles differ in structure and attributes of the integral individuality (neurodynamic, psychodynamic, personal, socio-psychological).

\section{Method}

\section{Participants}

In the first phase of the study, I recruited 480 participants (240 men and 240 women), aged 18-40, who attended the entry-level courses for firefighters offered by the State Firefighting Service of the Emergency Ministry of the Udmurt Republic and students of the Udmurt State University (Faculty of Psychology and Pedagogy, Institute of Social Communications, Higher College of Mathematics and Informatics and College of Social Technologies and Service).

For the second phase of the study, I recruited 260 fulland part-time students of the Udmurt State University (130 girls and 130 boys, aged 19-24).

\section{Materials}

To study various components of communicative activity, I used Krupnov's Judgment Test (Ratanova \& Shlyahta, 1998). It employs the systems approach to the study of various personal attributes, advanced by Krupnov (1995). The test consists of 140 questions and detects the following components of communicative activity: dynamic (natural), sthenic and asthenic, motivational dimension, cognitive dimension, regulatory dimension, productive dimension, as well as two types of communication difficulties. The first type of difficulties is explained by the lack of communication skills, whereas the second type includes personal qualities such as shyness, unsociability, low selfesteem, etc.

The students' individual psychological attributes were determined using the following instruments, designed to study various hierarchical levels of individuality.

The characteristics of the nervous system (neurodynamic qualities) were diagnosed using Strelyau's Personal Questionnaire (Eliseev, 2001). The questionnaire is designed to study the main characteristics of the nervous system: excitation, inhibition, and mobility of nervous processes. The underlying concept is based on the Pavlov's theory of higher nervous activity, according to which the above-mentioned processes form certain combinationstypes of nervous system. Depending on the strength of the excitation process, strong and weak types are described. Depending on the ratio of excitation and inhibition, strong types are classified into balanced and unbalanced. Strong balanced types are further divided into mobile and immobile. The questionnaire includes 134 multiple-choice questions with "yes," "no," and "don't know" response options. The addition of the points obtained constitutes the assessment of the expression of each quality.

Psychodynamic attributes were studied using the Rusalov's (1985) Temperament Structure battery (V-OST; Eliseev, 2001). Rusalov's questionnaire is based on the concept of biological conditionality of formal dynamic attributes of individual behavior, based on Pavlov's ideas. The structure of temperament is comprised of four fundamental characteristics: ergicity, plasticity, speed (tempo), and emotional sensitivity. In his temperament model, Rusalov defines two aspects of the person's interaction with the environment: interaction with the object world and interaction with the social world, allowing the description of two aspects of ergicity—objects/activity and communicative- two aspects of plasticity, two aspects of speed, and two aspects of emotional sensitivity-toward things and people. The questionnaire contains 105 questions and generates eight temperamental scales.

Personality characteristics were studied using Cattell's 16 Personality Factor Questionnaire (16-PF; Cattell, Saunder, $\&$ Stice, 1994). This questionnaire is designed to measure 
sixteen personality factors and provides exhaustive information on personality traits. It gives a detailed description of the personality structure, links between various personality characteristics, and it detects personal problems, if present. The questionnaire contains 187 questions. The reliability coefficient of the 16-PF lies between .71 and .91, with retest reliability coefficient (in a 2 -week interval) between .56 and .73 .

Gender characteristics were measured with the Bem Sex Role Inventory (BSRI; Bem, 1974). The instrument was proposed by Bem to diagnose masculinity and femininity and contains 60 items (characteristics), each of which the person marks as "yes" or "no," assessing the presence or absence of certain characteristics.

Socio-psychological characteristics were studied using the modified Leary's Interpersonal Behavior Circle (Leary, 1957; adapted by Sobchik, 1990. The questionnaire contains 128 items for self-assessment of personality characteristics, which determine the dominant type of behavior.

Perceptions of a difficult communication partner of the same and opposite sex were studied using the SocioPsychological Characteristics of a Communication Subject Questionnaire by Labunskaya (Labunskaya et al., 2001). The battery contains 68 characteristics, belonging to five groups of psychological difficulties in communication: expression/speech, social/perceptive, relations/addresses, interaction skills, and communication environment. Each group includes both positive and negative traits, determining communication efficiency. Participants are asked to rate the extent to which a certain peculiarity of the partner's behavior obstructs communication. Response options range from 1 (doesn't obstruct) to 5 (obstructs strongly), with a 0 option (don't know). Points within each group of psychological difficulties are first added. Then the value from each group is converted into a 20-point scale. The total value of different groups of characteristics allows assessing the degree of individual or group sensitivity to different aspects of communication (the concept of psychological communication difficulties) and sensitivity to positive and negative trends in communication, as well as compiling a representation of a difficult partner from the perspective of the group or the individual.

Participants completed test forms individually and in groups. Data was processed using the SPSS statistical package.

\author{
Data Analysis and Results
}

\section{Adult Samples}

Mean measures of communicative activity in male and female groups were compared using Student's $t$-test. As shown in Table 1, no significant differences between men and women were found in most components of the communicative activity (dynamic, emotional, motivational, and productive). Differences in the following measures were significant: internality, consciousness, and personal difficulties in communication. Women displayed stronger internal regulation of the communicative activity. They put greater effort and initiative into communication and they believed that they are largely responsible for their relations with others.

In the cognitive aspect, women showed greater consciousness. Women may have deeper understanding of the significant aspects of the communicative activity and its role in life and profession.

Gender differences were also found in personal communication difficulties, with women having more difficulties than men.

Factor analysis, with principle component analysis with varimax rotation, was employed to clarify the structure of communicative activity in male and female samples

I shall now discuss the rotated structure of communicative activity in the male sample. The following variables loaded significantly on Factor 1: egocentricity, ergicity, sthenia, sociocentricity, consciousness, asthenia, and objectivity. Thus, Factor 1 may be viewed as the motivational or affective component of communicative activity.

Factor 2 is comprised of personal difficulties, awareness, operational difficulties, subjectivity, and anergicity. Factor 2 thus describes communication difficulties.

Factor 3 is comprised of the following parameters: externality and internality. It is the regulatory or affective component of communicative activity.

In the female sample, factor analysis also yielded three factors.

With regard to the rotated structure of communicative activity in the female sample, Factor 1 includes the following variables: personal difficulties, operational difficulties, awareness, subjectivity, and anergicity. The factor describes difficulties in communication.

Table 1

Comparison of Mean Measures of Male and Female Communicative Activity

\begin{tabular}{lccrrr}
\hline & \multicolumn{3}{c}{$M$} & & \\
\cline { 2 - 4 } Measures of communicative activity & Men $(n=240)$ & Women $(n=240)$ & & $t$ \\
\hline Internality & $49,56(8,17)$ & $51,82(6,90)$ & -3.103 & .002 \\
Consciousness & $47,38(7,97)$ & $51,79(7,24)$ & -6.013 & -2.950 \\
Personal communication difficulties & $31,73(9,27$ & $34,24(8,28)$ & .000 \\
\hline
\end{tabular}


VASYURA

Table 2

Factor Analysis of the Communicative Activity Structure in the Male Sample

\begin{tabular}{rlcc}
\hline Parameters & Factor 1 & Factor 2 & \\
\hline 1 & Ergicity & .767 & .663 \\
2 & Anergicity & .743 & \\
3 & Sthenia & .644 & \\
4 & Asthenia & & \\
5 & Internality & & \\
6 & Externality & .713 & \\
7 & Sociocentricity & .814 & .835 \\
8 & Egocentricity & .686 & .834 \\
9 & Consciousness & & \\
10 & Awareness & .634 & .773 \\
11 & Objectivity & & .798 \\
12 & Subjectivity & & .839 \\
13 & Personal difficulties & & $19.8 \%$ \\
14 & Operational difficulties & $36.9 \%$ & $7.5 \%$ \\
Percentage of explained variance & & \\
\hline
\end{tabular}

Table 3

Factor Analysis of the Communicative Activity Structure in the Female Sample

\begin{tabular}{rlcc}
\hline Parameters & Factor 1 & Factor 2 & .739 \\
\hline 1 & Ergicity & & .697 \\
2 & Anergicity & & $\mathbf{. 6 2 2}$ \\
3 & Sthenia & & \\
4 & Asthenia & & \\
5 & Internality & & .852 \\
6 & Externality & & .762 \\
7 & Sociocentricity & & $\mathbf{. 5 6 0}$ \\
8 & Egocentricity & & \\
9 & Consciousness & .789 & .737 \\
10 & Awareness & & \\
11 & Objectivity & .775 & \\
12 & Subjectivity & .807 & \\
13 & Personal difficulties & .847 & \\
14 & Operational difficulties & $32.3 \%$ & \\
Percentage of explained variance & & \\
\hline
\end{tabular}

Factor 2 is comprised of such parameters as ergicity, objectivity, sthenia, asthenia, consciousness, and egocentricity. The factor describes the dynamic contents of communicative activity.

Factor 3 includes internality, externality, sociocentricity, egocentricity, asthenia, and consciousness. It is the motivational or affective component of communicative activity.

\section{Adolescent Samples}

Labunskaya's (2001) method was used to study males' concepts of a difficult communication partner of the same sex. These difficulties received the following mean scores (in descending order): relations-addresses (9.47), interaction skills (9.34), expressive-speech peculiarities of the partner (9.06), communication environment (8.80), and socioperceptive characteristics (8.39).

In communication with the opposite sex, the results were different: relations-addresses (9.68), communication environment (9.41), interaction skills (9.36), expressive-speech characteristics (9.28), and socio-perceptive characteristics (8.72).

I also analyzed such psychological concepts in the sample of girls. The mean scores of difficulties in communication with a partner of the same sex were as follows (in the descending 
order): relations-addresses (9.81), interaction skills (9.56), socioperceptive characteristics (9.09), expressive-speech characteristics (8.79), and communication environment (8.41).

And with male partners, the concept was quite the same, with a tendency toward higher mean scores: relationsaddresses (10.07), interaction skills (9.43), socio-perceptive characteristics (9.23), expressive-speech characteristics (9.13), and communication environment (8.84). Thus, our data (measured by the scale relations-addresses) shows that, for girls, a difficult communication partner is the one who displays negative attitude toward them.

To determine possible differences in concepts of difficult communication partners of the same and opposite sex in boys' and girls' samples, Student's $t$-test for dependent samples and five groups of communication difficulties was used. The comparative analysis in the girls' sample showed no significant differences. In the boys' sample, differences in socio-perceptive characteristics were found, $t=2.277, p$ $=.03$ ), indicating that, in the male sample, the psychological concepts of subjects of obstructed communication depend on the partner's sex. This means that, from the socioperceptive viewpoint, for boys, a girl is a more difficult communication partner than another boy.

To determine communicative styles in the adolescent boys' group, I performed factor analysis (principle component analysis Varimax rotation) of the communicative activity parameters and individual psychological characteristics. The analysis generated three factors, explaining $36.4 \%$ of the variance. Factor 1 is comprised of 27 parameters with significant factor loadings, 10 of which describe the communicative activity and 17 the different levels of the hierarchical individuality (see Table 4).

Parameters of Factor 1 suggest that boys displaying this communicative style easily make many new contacts and show their emotions. They express both ego- and sociocentric tendencies. Their communicative activity is conscious and practical. Such boys experience no operational or personal difficulties in communication. The individuality characteristics included in Factor 1 show that this communicative style is observed in boys with a strong, balanced, and mobile type of nervous system. They easily make new contacts and switch between activities, have a large number of communicative programs, and display high tempo of behavior and operations. Their speech is easy and smooth. Such boys are sensitive to failures, very sociable and open, emotionally stable and realistic, energetic and self-confident, sincere, daring, and responsive. They display expressed masculinity. In interpersonal relations, they are dominant, they strive to be leaders and guide others and are not inclined to give in or submit. This is a typical male communicative style, which may be called energetic and businesslike.

Factor 2 includes 17 parameters, with the communicative activity described by 6 parameters. It is noteworthy that such communicative style is inharmonious. Boys using this style have personal difficulties in communication; nevertheless, they express emotions and sociocentric motivation and make every effort to analyze their communicative activity and its role in their lives and professions. Boys with this style easily make new contacts and are flexible in communication, sensitive to study and communication failures. They are characterized by emotional instability, increased motivation, they are sensitive to the emotions of others, and follow their own beliefs. In interpersonal relations, they need acknowledgement, acceptance, and social approval, and are very ingenuous. Thus Factor 2 describes the conforming, emotional communicative style.

Factor 3 includes 4 parameters of communicative activity and 10 individual attributes. Boys with this structure of communicative activity display expressed regulation of their communicative activity, sociocentric motivation, and consciousness of their communicative actions. They have an unbalanced type of nervous system, are very tactful and diplomatic, trusting, tolerant, and shrewd, with expressed femininity. They say no sharp words to others, do not criticize, rely on external opinion, and crave acknowledgement and social approval. This communicative style may be called diplomatic and externally oriented.

As seen in Table 5, in the girls' sample, factor analysis of the correlations of communicative activity parameters and individuality characteristics was also performed. The analysis generated 3 factors, explaining $36.6 \%$ of the variance.

Factor 1 includes 27 parameters, 12 of which describe communicative activity. It shows that girls take initiative in communication, have a broad circle of contacts, and are dominated by sthenic emotions (joy, admiration, etc.). These girls display the external type of regulation of their communicative activity, because they think that their relations with communication partners are conditioned by the environment. Their communicative motivation is ambivalent, as it includes both egocentric and altruistic tendencies. Girls possessing such a communicative style are aware of main functions of communication, with their communication aimed at achieving practical goals. Thus, the communicative style corresponding to Factor 1 is common to girls with a strong and mobile type of nervous system. They crave communication, easily make new contacts, and like diverse activities. Such girls automatically enter social relations, show high behavior tempo and speed of operations. They are cordial and open, energetic, joyful, and talkative, enterprising, and they need social approval. Such girls are characterized by expressed masculinity. In interpersonal relations, they are confident and persistent, and not inclined to give in or submit. Generally, this communicative style is energetic and sociable.

Factor 2 includes 16 parameters, with 6 of them describing communicative activity. This communicative style is inharmonious, and it includes both groups of communicative difficulties. They are accompanied by emotionality in social contacts, comprised of both sthenic and asthenic emotions. Such girls express superficial judgments. Girls with this communicative style are characterized as impulsive, sensitive to failures, and socially vulnerable. They are dominated by 
Table 4

Results of the Factor Analysis of Communicative Activity and Attributes of Integral Individuality in the Boys' Sample

\begin{tabular}{|c|c|c|c|c|}
\hline \multicolumn{2}{|c|}{ Parameters of communicative activity and individual psychological attributes } & Factor 1 & \multirow[t]{2}{*}{ Factor 2} & Factor 3 \\
\hline \multicolumn{4}{|c|}{ Parameters of communicative activity (Krupnov) } & \\
\hline 1 & Ergicity & 698 & & \\
\hline 2 & Anergicity & & & \\
\hline 3 & Sthenia & .579 & & \\
\hline 4 & Asthenia & .413 & .587 & \\
\hline 5 & Internality & & & .582 \\
\hline 6 & Externality & & & .586 \\
\hline 7 & Sociocentricity & .541 & & \\
\hline 8 & Egocentricity & 675 & & \\
\hline 9 & Consciousness & & .480 & \\
\hline 10 & Awareness & & .459 & \\
\hline 11 & Objectivity & .511 & & \\
\hline 12 & Subjectivity & & & \\
\hline 13 & Operational difficulties & -.503 & & \\
\hline 14 & Personal difficulties & -.477 & & \\
\hline \multicolumn{5}{|c|}{ Characteristics of the nervous system (Strelyau) } \\
\hline 15 & Strength of excitation & .769 & & \\
\hline 16 & Strength of inhibition & & -.449 & \\
\hline 17 & Balance & .518 & & \\
\hline 18 & Mobility & 680 & & \\
\hline \multicolumn{5}{|c|}{ Psychodynamic attributes (Rusalov) } \\
\hline 19 & Objective ergicity & & & \\
\hline 20 & Social ergicity & .567 & & \\
\hline 21 & Objective plasticity & 623 & & \\
\hline 22 & Social plasticity & & .423 & \\
\hline 23 & Objective tempo & .573 & & \\
\hline 24 & Social tempo & .605 & & \\
\hline 25 & Objective emotionality & & .462 & \\
\hline 26 & Social emotionality & & .565 & \\
\hline \multicolumn{5}{|c|}{ Personality characteristics (Cattell) } \\
\hline 27 & Factor A & .552 & & \\
\hline 28 & Factor B & & & \\
\hline 29 & Factor $\mathrm{C}$ & & -.473 & \\
\hline 30 & Factor E & .552 & & \\
\hline 31 & Factor F & .643 & & \\
\hline 32 & Factor G & & & \\
\hline 33 & Factor $\mathrm{H}$ & .778 & & \\
\hline 34 & Factor I & & & \\
\hline 35 & Factor L & & & -.409 \\
\hline 36 & Factor $\mathrm{M}$ & & & \\
\hline 37 & Factor $\mathrm{N}$ & & & .398 \\
\hline 38 & Factor $\mathrm{O}$ & & .433 & \\
\hline 39 & Factor Q 1 & & & -.398 \\
\hline 40 & Factor Q 2 & & & \\
\hline 41 & Factor Q 3 & & -.399 & \\
\hline 42 & Factor Q 4 & & .467 & \\
\hline \multicolumn{5}{|c|}{ Bem's Sex Role Inventory } \\
\hline 43 & Masculinity & .553 & & \\
\hline 44 & Femininity & & & .582 \\
\hline \multicolumn{5}{|c|}{ Interpersonal Behavior Circle (Leary) } \\
\hline 45 & Managerial - autocratic & .451 & & \\
\hline 46 & Independent - dominant & & & \\
\hline 47 & Straightforward - aggressive & & .399 & \\
\hline 48 & Mistrustful - skeptical & & & -.410 \\
\hline 49 & Submissive - shy & -.471 & & \\
\hline 50 & Docile - dependent & & .501 & \\
\hline 51 & Cooperative - over-conventional & & .394 & \\
\hline \multirow[t]{2}{*}{52} & Responsible - magnanimous & & & .388 \\
\hline & Ratio of explained variance $(\%)$ & 19 & 1.1 & 7.4 \\
\hline
\end{tabular}

Note. The table features the significant factor loadings. 
Table 5

Results of the Factor Analysis of Communicative Activity and Attributes of Integral Individuality in the Girls' Sample

\begin{tabular}{|c|c|c|c|c|}
\hline \multicolumn{2}{|c|}{ Parameters of communicative activity and individual psychological attributes } & Factor 1 & Factor 2 & Factor 3 \\
\hline \multicolumn{5}{|c|}{ Parameters of communicative activity (Krupnov) } \\
\hline 1 & Communicative ergicity & .782 & & \\
\hline 2 & Communicative anergicity & -.464 & & \\
\hline 3 & Sthenia & & .462 & \\
\hline 4 & Asthenia & & 621 & \\
\hline 5 & Internality & & & .355 \\
\hline 6 & Externality & .396 & & \\
\hline 7 & Sociocentricity & .470 & & \\
\hline 8 & Egocentricity & .662 & & \\
\hline 9 & Consciousness & .585 & & \\
\hline 10 & Awareness & & .569 & \\
\hline 11 & Objectivity & .439 & & \\
\hline 12 & Subjectivity & & .472 & \\
\hline 13 & Operational difficulties & -.636 & & \\
\hline 14 & Personal difficulties & -.650 & & \\
\hline \multicolumn{5}{|c|}{ Characteristics of the nervous system (Strelyau) } \\
\hline 15 & Strength of excitation & .499 & & \\
\hline 16 & Strength of inhibition & & -.637 & \\
\hline 17 & Balance & & .420 & \\
\hline 18 & Mobility & .474 & & \\
\hline \multicolumn{5}{|c|}{ Psychodynamic attributes (Rusalov) } \\
\hline 19 & Objective ergicity & & & \\
\hline 20 & Social ergicity & .715 & & \\
\hline 21 & Objective plasticity & .600 & & \\
\hline 22 & Social plasticity & .521 & & \\
\hline 23 & Objective tempo & .541 & & \\
\hline 24 & Social tempo & .583 & & \\
\hline 25 & Objective emotionality & & .541 & \\
\hline 26 & Social emotionality & & .552 & \\
\hline \multicolumn{5}{|c|}{ Personality characteristics (Cattell) } \\
\hline 27 & Factor A & .573 & & \\
\hline 28 & Factor B & & & \\
\hline 29 & Factor $\mathrm{C}$ & & -.468 & \\
\hline 30 & Factor E & .515 & & \\
\hline 31 & Factor $\mathrm{F}$ & .634 & & \\
\hline 32 & Factor $\mathrm{G}$ & & & \\
\hline 33 & Factor $\mathrm{H}$ & .749 & & \\
\hline 34 & Factor I & & & \\
\hline 35 & Factor L & & & -.420 \\
\hline 36 & Factor M & & & \\
\hline 37 & Factor $\mathrm{N}$ & & & \\
\hline 38 & Factor $\mathrm{O}$ & & .496 & \\
\hline 39 & Factor Q1 & & & -.388 \\
\hline 40 & Factor Q 2 & -.415 & & \\
\hline 41 & Factor Q 3 & & & \\
\hline 42 & Factor Q 4 & & .414 & \\
\hline \multicolumn{5}{|c|}{ Bem's Sex Role Inventory } \\
\hline 43 & Masculinity & .476 & & \\
\hline 44 & Femininity & & & .589 \\
\hline \multicolumn{5}{|c|}{ Interpersonal Behavior Circle (Leary) } \\
\hline 45 & Managerial - autocratic & .547 & & \\
\hline 46 & Independent - dominant & & & \\
\hline 47 & Straightforward - aggressive & & .499 & \\
\hline 48 & Mistrustful - skeptical & & .554 & \\
\hline 49 & Submissive - shy & -.451 & & \\
\hline 50 & Docile - dependent & & & .395 \\
\hline 51 & Cooperative - over-conventional & & & .693 \\
\hline \multirow[t]{2}{*}{52} & Responsible - magnanimous & & & .617 \\
\hline & Ratio of explained variance $(\%)$ & 18.3 & 11.4 & 6.9 \\
\hline
\end{tabular}

Note. The table features the significant factor loadings. 
emotions and do not argue in controversial situations. They have an expressed sense of guilt and impressionability, high motivation and irritability. Such girls display irony, stubbornness, and non-conformity, with their negativism sometimes expressed as verbal aggression. This style of communicative activity may be called emotional and difficult.

Factor 3 includes 11 parameters, with 3 of them describing communicative activity. This communicative style is typically feminine and characterized by sthenic emotions and flexible regulation of communicative activity. Girls with this style display strong inhibition capacity. They are characterized by conformity, softness and pliability. Such girls are tolerant, benevolent, easy to get on with, conservative, and accept only time-proven things. In interpersonal relations, they await help and advice, are polite, cannot show resistance, strive to agree with the opinion of others, display warmth and amicability. In general, Factor 3 describes a complaisant and expressive communicative style.

\section{Discussion}

This empirical study based on the systems approach revealed the characteristics of communicative activity in men and women and girls and boys. Absolute differences between male and female samples are scarce and lie in three of fourteen aspects of communicative activity (internality, consciousness and personal difficulties in communication). These data support the hypothesis that states that, although men and women do not differ in dynamic, emotional, motivational, and productive components of communicative activity, women display greater internality in communication and deeper awareness of its role in life and profession. Women experience more personal difficulties in communication.

Recent publications provide different empirical data on male and female internality/externality. Strickland and Haley (1980) found no significant gender differences as measured by the Rotter Scale. Nevertheless, when the tested persons of both sexes were asked to answer the questions from the position of a typical man, they scored higher on the internality scale, and when they answered as a typical woman would, they scored higher on the externality scale. In an adolescent sample, Tyrnova (1996) found greater internality in girls, which corresponds to our data. Tyrnova also showed that girls have more operational and personal difficulties in communication and pay more attention to their defects. Their communication is obstructed by shyness, low self-esteem, and distrustfulness. Our data shows gender differences only in personal communication difficulties. Possibly, the partial accordance of our data with that of Tyrnova may be explained by age differences.

In general, the differences in male and female communicative activity can be explained from the systems perspective. This approach states that gender differences are determined by the combination of biological and social factors. Groshev (2002) proposed a systems approach to gender problems. He notes: "While gender differences apply to all levels of personal activity (from spontaneous nonverbal-motor to complex social forms of behavior), they are a factor of integrity and one of the basic components of natural potentials. The influence of gender differences on personality, behavior, and activity is determined by both internal (biological, natural, and biogenetic) and external factors (environment, culture, upbringing, activity)" (p. 13). Thus, gender differences in internality, consciousness, and personal difficulties in communication may be viewed as a combination of innate and acquired factors.

The comparison of the factor analysis results in the male and female samples revealed differences in the structure of communicative activity. In these groups, personal difficulties in communication were included in different factors: Factor 2 in the male sample and Factor 1 in the female sample. In general, it can be concluded that, firstly, communication difficulties are expressed more in women than in men and, secondly, there are clear differences in the mechanism of communicative activity regulation: in men, the affective component prevails. The differences in the structure of communicative activity between the male and female samples show the specifics of each of them.

These data shows that psychological representations of subjects of obstructed communication of the same and opposite sex are different in girls and boys aged 19-24. The results obtained using the Labunskaya et al.'s (2001) method also show that the female concept of a difficult communication partner has no gender-specific characteristics. Male concepts of subjects of obstructed communication of the same or opposite sex differ in several socio-perceptive characteristics. Possibly, this can be explained by the differences in interpersonal roles of girls and boys. In accordance with these roles, boys show initiative in acquaintance and communication with girls, whereas girls respond to their initiative and play a more passive role. If a girl shows poor understanding, low sensitivity, and astuteness, she is perceived as a difficult communication partner. At the same time, these qualities in a boy cause less difficulties in the boy-to-boy communication.

My data also shows that male and female perceptions of a difficult communication partner are based on relationsaddresses, that is, characteristics such as hostility, arrogance, indifference, and dominance.

I identified three different communicative styles in boys, determined by different-level features of individuality: "energetic, businesslike," "conforming, emotional," and "diplomatic, externally oriented." The first two styles are determined by neurodynamic, psychodynamic, personal, and socio-psychological attributes of integral individuality. The third style is determined by neurodynamic, personal, and socio-psychological characteristics of individuality. Two of three styles in boys have gender components: masculinity in the "energetic, businesslike" style and femininity in the third style, "diplomatic, externally oriented".

I also determined three female communicative styles. These styles are determined by different attributes belonging 
to various levels of their integral individuality: "energetic, sociable," "emotional, difficult," and "complaisant, expressive." The first two styles are determined by a set of neurodynamic, psychodynamic, personal, and sociopsychological characteristics of integral individuality, and the third style by neurodynamic, personal, and sociopsychological attributes of individuality. Similarly to the male sample, two of three styles have gender components: masculinity in the first style and femininity in the third one.

Thus, communicative styles in girls and boys are determined by natural and social levels of integral individuality. Each style is determined by a specific complex of different-level features of integral individuality.

Not all of these styles are productive and harmonic. The "conforming, emotional" style in boys and "emotional, difficult" style in girls may not only obstruct communication, but also hinder the development of student individuality. This conclusion is based on two peculiarities of these communicative styles in boys and girls. First, these styles lead to communicative difficulties; second, they include emotionality. Consequently, one of the ways to overcome difficulties in communication is the regulation of emotional patterns of reaction in various communicative situations.

These data allow the creation of individual correctivedeveloping programs for adolescents. Such programs should be specifically geared to the components of the communicative activity which obstruct communication.

I have developed and validated a program for the development of communicative activity in students. The program is purpose-designed to: (a) develop self-actualization and awareness of other people, (b) form communicative skills, and (c) teach adolescents to develop themselves as subjects of communicative activity.

The program features psychological education, diagnosis, consulting, and individual and group psychological correction. It is also noteworthy that group psychological correction should always be performed in mixed student groups. Cooperation of boys and girls will allow us to model the most common life and study situations and understand gender specifics of communicative activity.

\section{Conclusions}

The differences in absolute parameters of male and female communicative activity are significant. In women, components of communicative activity such as internality, consciousness, and personal communication difficulties are more expressed.

Communicative activity is a complex multi-component phenomenon, the structure of which is different in men and women. Communicative activity regulation is also different: in men, the affective component is prevalent, whereas women are dominated by motivation.

Psychological representations of communication partners of the same or opposite sex are different in the male and female samples. Boys differentiate communication partners of the same and opposite sex by their socio-perceptive characteristics.

Adolescent communicative styles are identified as: "energetic, businesslike," "conforming, emotional," and "diplomatic, externally oriented" in boys and "energetic, sociable," "emotional, difficult," and "complaisant, expressive" in girls. I have shown that male and female communicative styles are determined by different individual characteristics.

For adolescents with inharmonic communicative styles, I propose a program designed to develop their communicative activity and that may be applied by psychologists.

\section{References}

Bem S.L. (1974). The measure of psychological androgyny. Journal of Consulting and Clinical Psychology, 42, 155-162. (Russian translation: Ilyin, E.P. (2002). Differentsialnaya psyhofisiologiya muzchiny $i$ zhenshiny (Differential psychophysiology of men and women) Saint-Petersburg: Piter.)

Bem S.L., Martyna W., \& Watson, C. (1976). Sex typing and androgyny: Further explorations of the expressive domain. Journal of Personality \& Social Psychology, 34, 1016-1023.

Bertalanfy, L. von. (1968). General system theory. Foundations, Development, Applications. New York: George Braziller.

Bodalev, A.A. (1996). Psih_logia obschenia (Psychology of communication). Moscow: Institut prakticheskoy psihologii. Voronezh: NPO "MODEK".

Burakova M.V. (2000). Interpretatsia masculinnosti-feminnosti vneshnego oblika zhenschini (na primere pricheski) (Interpretation of masculinity-femininity of woman appearance (by the example of haircut). Ph.D. thesis. Rostov-on-Don, Rostov State University.

Buunk, B.P., Vanyperen, N.W., Taylor, S.T., \& Collins, P.L. (1991). Social comparison and the drive upward revisited: Affiliation as a response to marital stress. European Journal of Social Psychology, 21, 529-546.

Cattell, R.B., Saunder, D.R., \& Stice, G. (1994). 16 Personality Factor Questionnaire ( $5^{\text {th }}$ ed.). Champaign, IL: Institute for Personality and Ability Test. (Russian translation: Eliseev, O.P. (2001), Praktikum po psihologii lichnosti [Practical studies in individual psychology]. Saint-Petersburg, Russia: Piter.)

Eagly, A.H. (1995). The science and politics of comparing women and men. American Psychologist, 50, 145-158.

Eliseev, O.P. (2001), Praktikum po psihologii lichnosti (Practical studies in individual psychology). Saint-Petersburg, Russia: Piter.

Eshbi, U.R. (1959). Vvedenie v kibernetiku/Perevod s angliiskogo Lakuri D.G. Pod. red. Uspenskogo V.A. (Basics of cybernetics) [Translation by D.G. Lakuti. Moscow: Inostrannaya literature (Foreign literature).

Gorbunov, Yu.Ya. (1992). Indidualny stil volevoi aktivnosti i ego formirovanie u starshih shkolnikov (Senior pupils' individual style of volitional activity and its forming): Doctoral dissertation. Perm State Pedagogical University. Perm, Russia. 
Groshev, I.V. (2002). Psihlogia polovyh razlichi (Psychology of gender differences): Doctoral dissertation. Moscow: Rossiiski universitet druzhbi narodov (Peoples' Friendship University of Russia).

Helgeson ,V.S. (1994). Relation of agency and communion to wellbeing: Evidence and potential explanation. Psychological Bulletin, 116, 412-428.

Kon, I.S. (1988). Vvedenie v seksologiu (Basics of sexology). Moscow: Meditsina.

Kornienko, D.C. (2001). Gendernie razlichia v structure kommunikativnoy aktivnosti/ Psiholohia XXI veka (tezisi mezhdunarodnoy mezhvuzovskoy nauchno-prakticheskoy konferentsii /pod. red. Krilova A.A. (Gender differences in the structure of communicative activity/ Psychology of the XXI century (Theses of international interuniversity research and practical conference)). Saint-Petersburg State University, 228-229.

Kornienko, D.S. (2003). Kommynikativnaya aktivnost $v$ strukture integralnoy individualnosti: geneticheski i ontogeneticheski aspekty (Communicative activity in the structure of integral individuality: genetic and ontogenetic aspects). Doctoral dissertation. Perm State Pedagogical University. Perm, Russia.

Krupnov, A.I. (1995). Psihologicheskaya problema obschitelnosti kak sistemnogo kachestva lichnosti (Psychological nature of sociability as an individual systems characteristic). Gumanizatia obrazovania, 3, 64-70.

Kuznetsova, I.K. (1987). Psihologicheskie osobennosti opredelennogo pola $v$ yunosheskom vozraste (Psychological peculiarities of gender in adolescence). Doctoral dissertation. Moscow.

Labunskaya, V.A., Medzheritskaya, Ya.A., \& Breys, E.D. (2001). Psihologia zatrudnennogo obshenia (Psychology of obstructed communication). Moscow: Academiya.

Leary, T. (1957). Leary's Interpersonal Behavior Circle: An interpersonal diagnosis of personality. New York: Ronald Press Company.

Merlin, V.S. (1981). Systemny podhod k ontogenezu integralnoy individualnosti (System approach to the ontogenesis of integral individuality). In Antsyferova, L.I. (ed.) Psihologia formirovania i razvitia lichnosty (pp. 87-105) (Psychology of personality forming and development). Moscow: Nauka.

Moshkina, L.D. (2000). Polovie osobennosti integralnoy individualnosti studentov (Sexual peculiarities of integral student individuality). Dcotoral dissertaton. Perm State Pedagogical University. Perm, Russia.

Pavlov I.P. (1951). Polnoe sobranie sochineniy (Complete set of works). Moscow: Gosizdat.

Pogolsha V.M. (1998). Sotsialno-psihologicheski potentsial lichnogo vliyania (Socio-psychological potential of personal influence). Doctoral dissertation. Saint-Petersburg State University.

Ratanova, T.A., \& Shlyahta, N.F. (1998). Psyhodiagnosticheskie metody izucheniya lichnosti (Psycho-diagnostic methods of personality research). Moscow: Moskovskii psyhologo-sotsialnyi institut Flinta.

Rudey, O.A. (1987). Psihologicheskie uslovia ucheta polovozrastnyh osobennostey podrostkov pri organizatsii obchestvenno poleznogo truda (Psychological conditions of accounting gender and age specifics in the organization of socially useful work): Doctoral dissertation. Moscow State University.
Rusalov, V.M. (1985). O prirode temperamenta I ego meste v structure individualnih svoistv cheloveka.//Voprosi psihologii. (About the nature of temperament and its place in the structure of individual characteristics of a person). Questions of Psychology, 1, 19-33.

Shmykov, V.I. (1996). Indidualny stil kommunikativnoy aktivnosti osuzhdennyh (Individual communicative style of convicts). Psihologichesky zhurnal, 3, 44-52.

Sobchik, L.N. (1990). Diagnostika mezhlichnostnih otnosheniy, Modifitsirovannyi variant interpersonalnoi diagnostiki T. Leary. Metodicheskoe rukovodstvo (Diagnostics of interpersonal relations. Modified version of interpersonal diagnostic of T.Leary. Methodical guidelines). Moscow: IKA "Moskva".

Strickland, B.R., \& Haley, W.E. (1980). Sex differences on the Rotter I-E Scale. Journal of Personality and Social Psychology, 39, 930-939.

Tannen, D. (1991). You just don't understand. Women and men in conversation. London, Virago Press.

Tyrnova, O.A. (1996). Psihologicheskie razlichia v proyavleniyah obschitelnosti u yunoshei i devushek (Psychological differences of sociability in adolescents). Doctoral dissertation. Moscow: Rossiiski universitet druzhbi narodov (Peoples' Friendship University of Russia).

Ustalov V.A. (2006). Stil psihologicheskoy zashiti v strukrture integralnoy individualnosti. Avtoreferat dissertatsii.(Style of psychological defense in the structure of integral individuality) Abstract from Ph.D. thesis. Perm: Perm State Pedagogical University.

Vasyura, S.A. (2002). Osobennosti kommunikativnoy aktivnosti yunoshei i devushek (na primere studentov faculteta fizicheskoy kultury) (Peculiarities of communicative activity in adolescence [on an example of students of the Sports Faculty]). Vestnik Permskogo Pedagogicheskogo Universiteta. Fizkultura i Sport, 1, 51-66.

Vizgina, A.P., \& Panteleev, S.R. (2001). Proyavlenie lichnostnyh osobennostey v samoopisaniyah muzhchin i zhenshin (Selfdescribed personal peculiarities in men and women). Voprosy Psihologii, 3, 91-100.

Volochkov, A.A. (2002). Uchebnaya aktivnost v integralnom issledovanii individyalnosty (Education activity in integral research of personality). Doctoral dissertation. Perm State Pedagogical University. Perm, Russia.

Vyatkin, B.A. (2006). Gendernye razlichiya v integralnom issledovanii individualnosti (Gender differences in the integral research of personality). Vestnik Permskogo pedagogicheskogo universiteta. Psychology, 2, 13-24.

Yufereva, I.I. (1985). Obrazy muzhchin i zhenscchin v soznanii podrostkov (Male and female images in teenager perception). Voprosy psihologii, 3, 84-90.

Znakov V.V. (2005) Psihologia ponimania: problemi $i$ perspektivi.(Psychology of comprehension: problems and outlooks. Moscow: Institute of psychology of Russian Academy of Science.

Received July, 10, 2006

Revision received March, 10, 2007

Accepted June, 27, 2007 